\title{
Perception of pregnant women towards caesarean section in Nigeria: a case study of a missionary hospital in Edo state, Nigeria
}

\author{
Felicia E. Amiegheme ${ }^{1}$, Florence Oluyemisi Adeyemo ${ }^{2}$, Olayinka A Onasoga ${ }^{3}$
}

\author{
${ }^{1}$ Department of Nursing Science, School of Basic Medical Sciences, College of Medical Sciences, University of Benin, \\ Benin city, Nigeria \\ ${ }^{2}$ College of health sciences, Ladoke Akintola University of technology, Ogbomoso, Oyo State, Nigeria \\ ${ }^{3}$ Niger Delta University, Wilberforce Island, Bayelsa, Nigeria
}

Received: 25 June 2016

Accepted: 12 July 2016

\author{
*Correspondence: \\ Dr. Felicia E Amiegheme, \\ E-mail: feliamies@yahoo.com
}

Copyright: () the author(s), publisher and licensee Medip Academy. This is an open-access article distributed under the terms of the Creative Commons Attribution Non-Commercial License, which permits unrestricted non-commercial use, distribution, and reproduction in any medium, provided the original work is properly cited.

\begin{abstract}
Background: The perception of pregnant women towards caesarean section (CS) even in the face of danger has been a major concern. The major objective of the study was to investigate the perception of pregnant women attending a missionary hospital in Edo state, Nigeria. A simple random sampling technique was used to select one hundred pregnant women from the antenatal clinic the hospital.

Methods: Data were collected using a structured questionnaire and analyzed using descriptive statistics in form of frequency, percentages and tables, t-test and one way analysis of variance (ANOVA) at the significance level of 5\%.

Results: Findings revealed that perception of pregnant women towards caesarean sections is negative/low, 79\% objected delivery via CS for fear of death while $82 \%$ objected due to family preference of vaginal delivery. $60 \%$ also objected because of the cost of undergoing CS. Findings further revealed that the group of respondents who have experienced caesarean section have a more positive perception towards caesarean section than the group who haven't. Conclusions: This study clearly indicate that there is a negative perception of pregnant women in this setting and majority of them were clearly adverse to CS. Educational level also significantly influences the perception of pregnant women towards caesarean section. It is therefore recommended that proper education of the masses be done so as to correct the wrong notions about caesarean section.
\end{abstract}

Keywords: Perception, Pregnant women, Caesarean section

\section{INTRODUCTION}

Caesarean section is a surgical procedure in which one or more incisions are made through a mother's abdomen (laparotomy) and uterus (hysterotomy) to deliver one or more babies, or to remove a dead fetus. ${ }^{1}$ It is one of the most important operations performed in obstetrics and gynaecology. Its life saving value to both mother and fetus has increased over the decades although specific indications for its use have changed. Its purpose of preserving the life of a mother with obstructed labour and delivering a viable infant from a dying mother have gradually expanded to include the rescue of the fetus from subtle dangers. ${ }^{2}$ If there are no complications, a vaginal birth is safer than a CS. Advantages of having a CS especially when it has been planned over the vaginal births includes: no contraction, minimized risk of prolapse, no vaginal injury and reduced bleeding while its disadvantages includes: increased cost, uterine rupture and increased probability of complications.

Various factors such as: prolonged labour, foetal distress, cord prolapse, uterine rupture, placental problems like placenta praevia, placenta accreta, abnormal presentation 
like breech or transverse positions, failed instrumental delivery, macrosomia, contracted pelvis etc can precipitate caesarean section. Other precipitating factors include lack of obstetric skill in performing breech births, multiple births, and improper use of technology (Electric Fetal Monitoring (EFM). ${ }^{1,3,4}$

The rate of C/S in developed countries are increasing as there has been a higher rate of acceptability over time while developing countries are struggling with the issue of non-acceptance of $\mathrm{C} / \mathrm{S}$ even in the face of inherent danger/risk. ${ }^{5}$ This negative perception has led to underutilization of the procedure. Due to the current safety of the procedure for both the mother and baby, the rates of $\mathrm{C} / \mathrm{S}$ in developed nations like in North America and Europe has been increasing with the United States of America recording an average of $26.1 \%$. China has been cited as having the highest rates of caesarean section in the world at $46 \%$ as of $2008 .^{3}$ In Nigeria, Geidam et al recorded $11.6 \%$ as the rate of caesarean section in the University College Hospital Ibadan between 2000-2005; Swende recorded $10.4 \%$ rate at the federal medical centre Markudi between 2004-2006 while Chigbu and Iloabachie obtained $25.3 \%$ at the University teaching hospital, Enugu state, Nigeria between 2001 and 2005. ${ }^{6-8}$ Australia recorded a surge from $21 \%$ to $31.9 \%$ between 1998 and 2007. While the overall rate of caesarean birth is lower in the UK, accounting for almost $25 \%$ of all births from 2007 to 2008, it has however increased by approximately $50 \%$ from $1995-1996 .{ }^{6}$ Birth rates via CS vary considerably across Europe, ranging from an average of $15 \%$ in Norway and the Netherlands, $17 \%$ in Sweden and Finland and increasing to $37.8 \%$ in Italy. ${ }^{9}$ Literature reveals that although caesarean section is a consensus idea in developed countries; in developing countries social and cultural paradigm is for women to reject caesarean section due to certain beliefs. It was observed that education and past vaginal experiences can also be a reason why women would most likely turn down caesarean section. ${ }^{10}$

Women turn down caesarean section for various reasons which includes: maternal fear of death during surgery based on death of close relatives, past unpleasant experiences in previous caesarean sections and unpleasant stories that they had heard from other women, desire to experience vaginal delivery, perception that caesarean section was an indication of reproductive failure, economic factor, inadequate counselling in the course of antenatal care, complaints of uncaring or casual attitude of the doctors when giving the information, religious belief in prophecies given that one would have a normal delivery. ${ }^{8}$

This study therefore aimed at identifying the perception of pregnant women attending antenatal clinic in Edo state, Nigeria towards the acceptance of caesarean section.

\section{METHODS}

Design: The design used by the researchers is the survey method.

\section{Study population}

The population was drawn from the pregnant women attending the antenatal clinic at a Missionary hospital in Edo state, Nigeria with a total population of 267 . It comprises pregnant women between 20 and 40 years.

\section{Study period}

Between July 2015 and September 2015

\section{Sampling technique}

Taro Yamane techniques formula at $\mathrm{p}=0.05$ was used to get the sample size of 100 and a simple random sampling method was used to select 100 pregnant women from the antenatal clinic.

\section{Instrument}

A self-structured questionnaire was developed to suit the needs of this study. The questionnaire had two sections, section A was the demographic information of the respondents and section $\mathrm{B}$ sought information about the variables selected for study (previous pregnancy, knowledge about CS, delivery options). Closed ended questions were asked. Experts and colleagues were given for validation a test retest method was used to test the reliability of the instrument and a reliability coefficient of 0.83 was obtained.

\section{Data collection}

one hundred questionnaires were distributed and retrieved for data analysis

\section{Data analysis}

Data collected were entered into the PASW 18 and analyzed using descriptive statistics in form of percentage and frequency tables, t-test and one way analysis of variance (ANOVA) were used at the significance level of $5 \%$.

\section{Ethical consideration}

Permission was sought from the research committee of the Missionary hospital and this was granted. Individual permission from the respondents in the antenatal clinic and only those who accepted were used for the study. The objectives and methods of the study were explained to those that participated in the study.

\section{RESULTS}

The above result assessed the knowledge and perception of pregnant women towards CS. The above result implies 
that the respondents' knowledge towards CS is low and overall, their perception is negative.

Table 1 shows majority of the respondents were within the age group of 20-30 years, $84 \%$ were Christians, and $50 \%$ had tertiary education.

Table 1: Socio-demographic status of respondents

$$
(\mathbf{n}=\mathbf{1 0 0}) \text {. }
$$

\begin{tabular}{|lll|}
\hline Variables & Frequency & Percentage (\%) \\
\hline Age in years & & \\
$20-30$ & 66 & 66 \\
$31-40$ & 34 & 34 \\
\hline Religion & & \\
Christianity & 84 & 84 \\
Islam & 16 & 16 \\
Others & - & - \\
\hline Level of & & \\
education & & 10 \\
Primary & 10 & 38 \\
Secondary & 38 & 50 \\
Tertiary & 50 & 2 \\
No formal & 2 & \\
education & & 50 \\
\hline Occupation & & 44 \\
Civil servant & 50 & 6 \\
Trading & 44 & \\
Farming & 6 & \\
\hline
\end{tabular}

In Table 2 result assessed the knowledge and perception of pregnant women towards CS. The above result implies that the respondents' knowledge towards CS is low and overall, their perception is negative.

Table 3 shows the responses of respondents to commonest factor responsible for non-acceptance of CS with two options of either "yes, or no". As revealed in Table $3,79 \%$ of the respondents indicated that they refused acceptance of CS for fear of death and $82 \%$ indicated that family preference of vaginal delivery is the reason for their rejection of CS. $60 \%$ indicated that cost is a reason why they refused $\mathrm{CS}$.

Result in Table 4 shows independent t-test of respondent's view of perception towards caesarean section; the calculated t-value of 6.17 is greater than the critical t-value of 1.96 at 0.05 level of significance. This implies that, there is significant perception difference between those that have undergone CS before and those that hasn't. The group of respondents who have experienced caesarean section have higher mean value than the group that ticked that they have not experienced caesarean section. $(\mathrm{M}=10.56 ; \mathrm{SD}=1.01) ;(\mathrm{M}=8.37 ; \mathrm{SD}$ $=1.14$ ) mean difference $=2.19$.
Table 5 showed that the calculated F-ratio 7.24 is greater than the critical F-ratio of 2.30 when compared. This means that educational level will significantly influence perception of pregnant women towards CS.

Table 2: Respondents knowledge and perception towards caesarean section.

\begin{tabular}{|c|c|}
\hline Questions & $\mathbf{N}(\%)$ \\
\hline \multicolumn{2}{|l|}{ Knowledge } \\
\hline \multicolumn{2}{|c|}{ Have you heard of caesarean section? $(n=100)$} \\
\hline Yes & $86(86 \%)$ \\
\hline No & $14(14 \%)$ \\
\hline \multicolumn{2}{|c|}{ Have you experienced caesarean section? $(n=86)$} \\
\hline Yes & $26(30.2 \%)$ \\
\hline No & $60(69.8 \%)$ \\
\hline \multicolumn{2}{|l|}{$\begin{array}{l}\text { Usual stay in the hospital after CS? } \\
(\mathrm{n}=100)\end{array}$} \\
\hline A week or less & $40(40 \%)$ \\
\hline More than 2 weeks & $60(60 \%)$ \\
\hline \multicolumn{2}{|l|}{$\begin{array}{l}\text { Blood may be transfused during or after } \\
\text { the procedure? }(n=100)\end{array}$} \\
\hline Yes & $55(55 \%)$ \\
\hline No & $45(45 \%)$ \\
\hline \multicolumn{2}{|c|}{ Can a woman achieve vaginal birth after CS? } \\
\hline Yes & $30(33 \%)$ \\
\hline No & $63(63 \%)$ \\
\hline Don't know & $7(7 \%)$ \\
\hline \multicolumn{2}{|l|}{ Perception: $(\mathrm{n}=100)$} \\
\hline Consider CS dangerous & $73(73 \%)$ \\
\hline Did not consider CS dangerous & $21(21 \%)$ \\
\hline No opinion & $6(6 \%)$ \\
\hline Would consider CS to save child's life & $89(89 \%)$ \\
\hline
\end{tabular}

Table 3: Commonest factors responsible for nonacceptance of CS.

\begin{tabular}{|ll|l|}
\hline Statement & Yes & No \\
\hline Fear of death & $79(79.0 \%)$ & $21(21.0 \%)$ \\
\hline $\begin{array}{l}\text { Family preference of } \\
\text { vaginal delivery }\end{array}$ & $82(82.0 \%)$ & $18(18.0 \%)$ \\
\hline Cost & $60(60.0 \%)$ & $40(40.0 \%)$ \\
\hline
\end{tabular}

Table 4: Independent t-test of perception difference between those that have undergone CS before and those that hasn't.

\begin{tabular}{|lccc|cc|}
\hline $\begin{array}{l}\text { Grouping } \\
\text { Variables }\end{array}$ & N & Mean & SD & $\begin{array}{l}\text { t- } \\
\text { value }\end{array}$ & Sig. \\
\hline $\begin{array}{l}\text { Prior CS } \\
\text { experience }\end{array}$ & 21 & 10.56 & 1.05 & 6.17 & .000 \\
\hline $\begin{array}{l}\text { No prior CS } \\
\text { experience }\end{array}$ & 79 & 8.37 & 1.14 & & \\
\hline *significant at $\mathrm{P}<.05 ; \mathrm{df}=98 ;$ critical $\mathrm{t}=1.96$. &
\end{tabular}


Table 5: One way analysis of variance of educational level and perception of pregnant women towards caesarean sections.

\begin{tabular}{|llllll|}
\hline Variable & $\mathbf{N}$ & Mean & SD & & \\
\hline $\begin{array}{l}\text { Non-formal education } \\
\text { /primary education }\end{array}$ & 22 & 6.97 & 2.00 & & \\
\hline Secondary education & 65 & 7.11 & 1.99 & & \\
\hline Tertiary education & 13 & 9.98 & 1.85 & F-value & Sig. \\
\hline Source of variance & SS & Df & Ms & 7.24 & .000 \\
\hline Between groups & 114.10 & 2 & 17.43 & & \\
\hline Within groups & 2397.43 & 97 & 11.54 & & \\
\hline Total & 25500.1 & 99 & & & \\
\hline
\end{tabular}

Significant at $\mathrm{p}<.05$; critical $\mathrm{F}_{(2,97)}=2.30$.

\section{DISCUSSION}

Vaginal birth has been considered as safe and very painful. ${ }^{10}$ Although perception of women towards CS is changing but there is still a wide knowledge gap between the developed countries and the developing ones. This study also shows that $79.0 \%$ indicated that they either refuse acceptance of caesarean sections for fear of death. The fear is majorly as a result of death of a close relative during caesarean section, past unpleasant experiences in previous caesarean sections and unpleasant stories from other women. ${ }^{8}$

Our study also shows that $82.0 \%$ refuse CS due to family preference to vaginal delivery. This negative acceptance may be due to ignorance and poor educational background. This finding agrees with Chigbu and Iloabachie who stated that one of the reasons given by women for turning down caesarean section was the desire to experience vaginal delivery. ${ }^{8}$ Myles also stated that they feel disappointed not to have experienced a normal delivery and they do not enjoy the accompanying sense of achievement. ${ }^{3}$

The study revealed that knowledge and perception of pregnant women towards caesarean section is negative/low with $73 \%$ considering CS as dangerous and $63 \%$ unaware that a vaginal birth is still possible after CS. However majority of the women would consider a CS to save the baby's life. This result is in agreement with the findings of Aziken et al who said that nonacceptance of CS was mainly due to inaccurate cultural perceptions of labour and caesarean section in the cohort of women. ${ }^{11}$

The study also showed that cost is a limiting factor to the acceptance of CS. $60 \%$ of the respondents indicated that the high cost of CS would make them prefer vaginal delivery. This is in line with the findings of Chigbu and Iloabachie which revealed that family economic pressure in a country with average monthly salary of 58 US dollars would make acceptance of CS difficult. ${ }^{8}$

Findings also revealed that the group of respondents who have experienced caesarean section have a more positive perception towards caesarean section than the group that have not experienced caesarean section. The negative perception of pregnant women that had no experience of caesarean section in Edo state, maybe attributed to the wrong perception that caesarean section is an indication of reproductive failure, which agrees with Osula that women may consider caesarean section as mutilation of their body as well as a sign of reproductive failure. ${ }^{12}$

This study clearly showed that educational level significantly influence the perception of pregnant women towards caesarean section. This finding agrees with Aziken et al who said that women's low level of education was most likely to be a factor for their nonacceptance of caesarean section. ${ }^{11}$

\section{CONCLUSION}

The prevalence of CS refusal is high and majority of the respondents have negative perception about CS. The findings showed that fear of death (79\%), family preference of vaginal delivery which is strongly linked with culture $(82 \%)$, cost $(60 \%)$ amongst other things are some of the reasons why respondents were adverse to CS. Perception of women towards CS in this environment can be improved by been birth prepared and complication ready with the involvement of men (husbands). The following recommendations are made based on findings of the study: 1). The nurses/midwives should health educate the women attending antenatal clinic on indications for caesarean section and all they need to know about caesarean section. 2). Obstetricians and nurses/midwives should make more effort to build confidence in their clients who are to undergo caesarean section, to allay fears associated with the surgery. 3). Government should organize seminars and campaigns through the use of posters, mass media etc, to correct wrong perceptions of the masses about caesarean section. Husband/family members should be encouraged to visit antenatal clinic with their wives on some occasions so as to be well informed about caesarean section from health education in the clinic. It will also create avenue for interaction with the health workers and foster cooperation from them thus discouraging preference for vaginal delivery in the face of danger. 
Funding: No funding sources

Conflict of interest: None declared

Ethical approval: The study was approved by the research committee of the Missionary hospital

\section{REFERENCES}

1. Van Dongen PWJ. Caesarean section: etymology and early history. South Afri J Obstet Gynecol. 2009;15(2):62-7.

2. Ruth D. Caesarean section: encyclopedia for sex and sexuality. 2007. Available at: www.sexualityencyclopedia/com/dr.

3. Myles M. A textbook for midwives, $14^{\text {th }}$ edition, Edinburgh, London, New York Oxford Philadelphia. St Louis Sydney, Toronto. 2010.

4. Van Ham MA, Van Dongen PW, Mulder J. Maternal consequences of caesarean section. A retrospective study of intraoperative and postoperative maternal consequences of caesarean section during a ten year period. Eur J Obstet Gynecol Reprod Biol. 1997;74(1):1-6.

5. Chigbu C, Iloabachie G. The burden of caesarean section refusal in a developing country setting. BJOG. 2007; 114:1261-5.

6. Geidam AD, Audu BM, Kawuwa BM, Obed JY. A retrospective review of caesarean section performed at the University of Maiduguri Teaching Hospital. Ann Afr Med. 2009;8(2):127-32.

7. Swende TZ. Emergency caesarean section in Federal Medical Centre Makurdi, Benue State, Nigeria. Niger J Med. 2008;17(4):396-8.

8. Chigbu C, Iloabachie G. The burden of caesarean section refusal in a developing country setting. BJOG-Int J Obstet Gynecol. 2007;114(10):1261-5.

9. Centers for disease control. Rates of caesarean delivery- United States, 1991.

10. Qazi Q, Akhtar Z, Khan K, Khan AH. Pregnant women view regarding cesarean section in Northwest Pakistan. Trop Med Surg. 2013;1:105.

11. Aziken M, Omo-Aghoja L, Okonofua F. Perceptions and attitude of pregnant women towards caesarean section in urban Nigeria. Acta Obstet Gynecol Scand. 2007;86(1):42-7.

12. Osula CO. Medical companion for everybody, $5^{\text {th }}$ edition, Benin City. Stevon Publications; 2002.

13. Bukar M, Audu BM, Massa AA. Caesarean delivery at Federal Medical Centre Gombe: a 3 year experience. Niger J Med. 2009;18(2):179-83.

Cite this article as: Amiegheme FE, Adeyemo FO, Onasoga OA. Perception of pregnant women towards caesarean section in Nigeria: a case study of a missionary hospital in Edo state, Nigeria. Int J Community Med Public Health 2016;3:2040-4. 